\title{
Provisional Measures in Icsid Arbitration from "Wonderland's Jurisprudence" to Informal Modification of Treaties
}

\author{
Tarcisio Gazzini \\ University of Lausanne, Switzerland \\ Tarcisio.Gazzini@unil.ch \\ Robert Kolb \\ University of Geneva, Switzerland \\ Robert.Kolb@unige.ch
}

\begin{abstract}
Since 1999, ICSID tribunals have almost systematically held that they have the power not only to recommend but also to order provisional measures under Article 47 of the ICSID Convention and Rule 39 of the Arbitration Rules. This article argues that the legal arguments offered by these tribunals are often not fully elaborated and in any case not entirely convincing. It then provides an alternative reading of the decisions relating to the mandatory character of provisional measures, in the sense that they imply a signifi- cant departure from the meaning the contracting parties recorded in the treaty. Yet, as the majority of ICSID members have endorsed, accepted or at least acquiesced in such departure, it appears that Article 47 of the ICSID Convention has beeninformally modi- fied through subsequent practice.
\end{abstract}

\section{Keywords}

provisional measures - ICSID Convention - investment arbitration - treaty interpretation - modification of treaties 
In a long stream of substantially identical decisions starting with Maffezini v. Spain, ICSID tribunals have upheld their power to order provisional measures under Article 47 of the ICSID Convention. Since Article 47 of the ICSID Convention expressly authorizes ICSID tribunals only to recommend such measures, it is worth examining the significance and implications of these decisions from the standpoint of the law of treaties.

The article first offers a concise discussion of the nature and role of provi- sional measures in the settlement of international disputes, before reviewing the leading cases of the International Court of Justice (ICJ) and other inter- national tribunals (sections II to IV). It then briefly describes the emergence of what appears to be a jurisprudence constante in ICSID investment arbitra- tion (section V) and examines the persuasiveness of the underlying legal rea- soning (section VI). Section VII is dedicated to the attitudes of ICSID members with regard to these decisions. The final objective of the article is to appraise the impact of the concordant body of decisions in combination with the (lack of) reaction of Member States to the ICSID Convention from the standpoint of the interpretation and possibly the informal modification of Article 47.

The discussion is limited to the alleged competence of ICSID tribunals to order provisional measures. It does not deal with the relationship between provisional measures and jurisdiction nor the conditions under which provi- sional measures can be granted.

\section{Provisional Measures in the Settlement of International Disputes}

When a case is filed before an international tribunal, the object of the whole procedure is to settle the dispute and to grant effective remedies to the parties to the extent the claims, and possibly the counterclaims, brought forward are considered to have merit. The dispute concerns a network of material or im- material goods as well as subjective legal situations (rights and obligations). In the nature of things, the procedure takes some time and tribunals may grant interim protection or provisional measures, the purpose of which is "to pre- serve the respective rights of the Parties, pending a decision of the Court, and

1 See infra note 33. 
presupposes that irreparable prejudice shall not be caused to rights which are the subject of dispute in judicial proceedings".2

Provisional measures normally set up duties of abstention rather than call- ing upon the parties to perform possibly onerous actions. They are not made the object of a judgment. The latter is a jurisdictional act covered by the force of res judicata and flows from a contentious procedure during which the com- peting arguments of the parties are heard and the court decides on the claim. Provisional measures are rather pronounced through an order (ordonnance). This entails that in cases of urgency there is no need to go through the parties' arguments as ordinarily set out in written pleadings and presented at hearings. This course of procedure gives the matter the necessary flexibility: provisional measures can be altered during the proceedings and new ones can be granted. There is no res judicata attached to such measures, 3 with the possible excep- tion that an arbitral tribunal would violate procedural public policy if it de- parted from opinions expressed in a preliminary award rendered in the same case. 4 When the tribunal declines to exercise its jurisdiction or delivers the final judgment, the provisional measures automatically lose their function and expire. The "interim" protection thus gives way to the substantive "final" pro- tection of the rights and obligations at stake.

Although provisional measures are normally requested by the parties, 5 the issue of interim protection may also be raised in the interest of the tribunal in the proper administration of justice and effectiveness of the proceedings of which it is seized. If the final judgment's impact can be impaired by actions of the parties while the dispute is pending, the prestige of the tribunal and the effectiveness of its adjudication process could be heavily jeopardized. That is

2 Land and Maritime Boundary between Cameroon and Nigeria, Provisional Measures, Order of 15 March 1996, I.C.J. Reports 1996, p. 13, para. 35.

3 See C. Schreuer with L. Malintoppi, A. Reinisch, A. Sinclair, The ICSID Convention. A Commentary (2nd ed., 2009), 774-775. In Pey Casado v. Chile, infra note 33, para. 14, the tribunal held that "[i]l y a lieu d'ajouter que les mesures conservatoires, qui sont du reste pro- visoires par nature et par définition (comme l'observe avec raison la Partie défenderesse), peuvent être modifiées ou annulées en touttempsparle Tribunal, nejouissentpasdelaforce de res judicata [...]".

4 Swiss Supreme Court, Decision 4A_606/2013, 2 September 2014, as reported by P. Bärtsch, A. Truttmann, Swiss Supreme Court Clarifies Res Judicata Effect of Preliminary Award Rendered by same Arbitrators in same Proceedings, at http://www.swlegal.ch/getdoc/9923adda-688b -4e6e-8c4f-d4331ee7e48b/2014_Philippe-Baertsch_Aileen-Truttmann_Swiss-Supr.aspx.

5 Such a demand can be presented at any time during the proceedings. For the ICJ, see Article 73 (1), Rules of Court (1978). 
the reason why provisional measures can also be taken by tribunals on their own authority (proprio motu). 6

With regard to the binding effect of provisional measures, there are two schools of thought.7 On one hand, it has been argued, with regard to the pro- visional measures indicated by the ICJ, that their binding character is func- tionally indispensable as otherwise the very object of the entire proceedings, namely the protection of the parties' rights, would be frustrated. The argument is further buttressed by the principle of good faith in the sense that, once the parties have accepted the tribunal's jurisdiction, they also assume certain accessory obligations which are necessary to enable the tribunal to fully dis- charge its mission. 8 The binding nature of provisional measures has also been considered as inherent to the tribunal's function or dictated by logic. 9

On the other hand, some authors have maintained that there is no neces- sary symmetry between the final judgment and provisional measures. Inspired by the principle that the sovereignty of States should not be limited without a clear legal entitlement to do so, and fearing that a bold course on provisional measures could discourage States to accept the jurisdiction of the ICJ, they have argued that these measures ought to be considered non-binding unless

6 For the ICJ, see Article 75 (1), Rules of Court (1978).

7 For a full discussion, see R. Kolb, La bonne foi en droit international public (2000), 608 ff., or The International Court of Justice (2013), esp. 641-645.

8 See, in particular, L. Daniele, Le misure cautelari nel processo dinanzi alla Corte Internazionale di Giustizia (1993), esp. 150. In Quiborax v. Bolivia, infra note 33, para. 592, the tribunal held that "The principle of good faith involves the duty not to perform any act that would defeat the object and purpose of the obligation that has been undertaken by the parties, even if the act itself is not expressly prohibited by the provisions of the treaty" (footnote omitted).

9 According to G.G. Fitzmaurice, "The Law and Procedure of the International Court of Justice, 1951-1954", 34 British Yearbook of International Law (1958), 1, 122, "the whole logic of the jurisdiction to indicate interim measures entails that, when indicated, they are bindingfor this jurisdiction is based on the absolute necessity, when the circumstances call for it, of being able to preserve, and to avoid prejudice to, the rights of any par- ties, as determined by the final judgment of the Court". See also L. Collins, "Provisional and Protective Measures in International Litigation", 234 Recueil des Cours (1992-III), 9; L. Gross, "Some Observations on Provisional Measures", in Y. Dinstein et al. (eds.), International Law at a Time of Perplexity. Essays in Honour of S. Rosenne (1989), 307;

K. Oellers-Frahm, “Article 41", in A. Zimmermann, C. Tomuschat, K. Oellers-Frahm, C.J.Tams(eds.), The Statute of the International Court of Justice, A Commentary (2nded., 2012), 1038. 
the court or tribunal has been conferred the power to attach to them a binding character. 10

\section{Jurisprudence of the International Court of Justice}

According to Article 41 (1) of its Statute, the ICJ "shall have the power to indi- cate, if it considers that circumstances so require, any provisional measures which ought to be taken to preserve the respective rights of either party"..1 Prior to 2001, there was a "profound divergence in the views of authoritative commentators" as to whether provisional measures are binding. 12 The wording of the Statute is all but clear. The question of the binding nature of provisional measures was deliberately left open at the drafting stage of the Statute of the Permanent Court of International Justice (PCIJ) in 1920. The word "indicate" rather than "order" or "decide" may suggest non-mandatory measures; but, in reality, the word is compatible with either interpretation, since it is neutral. The words "ought to be taken" rather than "shall be taken" may also suggest some non-binding feature; but the corresponding French wording, predomi- nant in 1920, reads "doivent être prises", which conveys the idea of a binding character.

The practice of the Court was not conclusive for many years. Since no State requested a sanction for non-observance of provisional measures, the Court took only an oblique position on the question.13 In addition, the practice of States was inconclusive: some provisional injunctions were heeded by the

10 See, in particular, J. Sztucki, Interim Measures in The Hague Court (1983); H. Thirlway, "The Indication of Provisional Measures by the ICJ", in R. Bernhardt (ed.), Provisional Measures Indicated by International Courts (1994), 1.

11 The other authentic text reads "La Cour a le pouvoir d'indiquer, si elle estime que les circonstances l'exigent, quelles mesures conservatoires du droit de chacun doivent être prises à titre provisoire". In doctrine, see, in particular, S. Rosenne, Provisional Measures in International Law: The International Court of Justice and the International Tribunal for the Law of the Sea (2005); K. Oellers-Frahm, supra note 9, 1062-1069; J.J. Quintana, Litigation at the International Court of Justice (2015), Chapter 11.

12 R. Kolb, International Court of Justice, supra note 7, 644. See also L. Collins, supra note 9, esp. 216 ff.; S. Rosenne, supra note 11, esp. 34 ff.

13 In Vienna Convention on Consular Relations (Paraguay v. United States of America), Provisional Measures, Order of 9 April 1998, I.C.J. Reports 1998, p. 248, para. 41, the Court held that the "United States should take all measures". The French text more clearly reads: "Les Etats-Unis doivent prendre toutes les mesures". 
concerned party, while many other injunctions were finally not carried out.14 There was thus no clear opinio juris on the matter.

The situation changed in 2001 when the ICJ found that

[i]t follows from the object and purpose of the Statute, as well as from the terms of Article 41 when read in their context, that the power to indi- cate provisional measures entails that such measures should be binding, inasmuch as the power in question is based on the necessity, when the circumstances call for it, to safeguard, and to avoid prejudice to, the rights of the parties as determined by thefinaljudgment of theCourt.15

The mainpoint, according to the Court, istopreservetothefullextentitsown ability to properly fulfil its judicial function. The finding was consistently reit- erated in subsequent decisions.

In 2007, the ICJ further held that the finding in the LaGrand decision on the mandatory character of provisional measures merely clarified (rather than developed) the meaning that Article 41 of the Statute had always had, with the consequence that it was applicable to measures adopted before 2001. It observed that

its 'orders on provisional measures under Article 41 [of the Statute] have binding effect' (LaGrand [...]). Although the Court only had occasion to make such a finding in a judgment subsequent to the Orders that it made in the present dispute, this does not affect the binding nature of those Orders, since in the Judgment referred to the Court did no more than give the provisions of the Statute the meaning and scope that they had pos- sessed from the outset. It notes that provisional measures are aimed at preserving the rights of each of the parties pending the final decision of the Court. The Court's Orders of 8 April and 13September1993indicating

14 K. Oellers-Frahm, supra note 9, 1065-1066.

15 LaGrand (Germany v.United States of America), Judgment, I.C.J. Reports 2001, p. 466, para. 102. In the literature, see, in particular, R.Y. Jennings, "The LaGrand Case", 1 The Law and Practice of International Courts and Tribunals (2002), 50; C. Tams, M. Memmecke, "The LaGrand Case", 51 International and Comparative Law Quarterly (2002), 449; R. Sloane, "Measures Necessary to Ensure: The ICJ's Provisional Measures Order in Avena and Other Mexican Nationals", 17 Leiden Journal of International Law (2004), 673; R. Kolb, "Note on the New International Case-Law Concerning the Binding Character of Provisional Measures", 74 Nordic Journal of International Law (2005), 117. 
provisional measures created legal obligations which both Parties were required to satisfy. 16

This statement might obscure rather than clarify the role of the Court. Article 41 of the Statute as it originally stood left the question of the binding nature of such measures entirely open. The drafting history, the text or the practice of the Court in its formative years do not yield any clear answers to the question. Thus, the 2001 decision is in reality a piece of legal craftsmanship based on te- leological and effectiveness considerations, with the aim of strengthening the judicial process at the ICJ and not losing ground with respect to tribunals, such as the International Tribunal for the Law of the Sea (ITLOS), which possess the power to indicate binding provisional measures.

The Court modestly veiled this part of judicial creativity by hiding behind the classic positivistic canon whereby the decision taken flows from the applicable norm in its original complexion. Lex semper loquitur. This fic- tion has perhaps a certain importance in international law where sovereign States are particularly sensitive to inroads into their sovereignty. Its function is to reassure States about the "proper behaviour" of the ICJ, which purportedly does not seek to carve out from the Statute more powers than States (origi- nally) granted to it. But itstands toreason thatinstitutional texts, as much as others, must notbeinterpreted only in the light of their historical sense. The interpreter can take into account later developments and engage in objective or dynamic interpretation of the meaning a provision should have today. This the Court did; and on that account it cannot be blamed.

Another aspect of the matter needs to be noted. Often, the analysis stops with the finding that provisional measures under Article 41 of the ICJ Statute have legally binding character. Apart from the fact that the ICJ could also issue non-binding measures if it found that through an appropriate course (who can do more can do less), little room is devoted to the exact consequences of that finding. It has been argued that the statement of the Court in LaGrand is disas- trous since it might affect the readiness of States to submit their disputes to the Court.17 This classic argument, used every time the Court has not deferred to the whims and wishes of a State, has no great weight: since 2001, there has been no significant change in the submission of cases to the Court.

16 Application of the Convention on the Prevention and Punishment of the Crime of Genocide (Bosnia and Herzegovina v. Serbia and Montenegro), Judgment, I.C.J. Reports 2007, p. 43, para. 452.

17 See H. Thirlway, “The Law and Procedure of the International Court of Justice, 1960-1989 (Part Twelve)", 72 British Yearbook of International Law (2001), 37, at 126. 
But taking now a look from another perspective, the question remains as to what consequences the breach of the provisional injunction entails. As with any breach of international obligations, non-compliance with binding pro- visional measures engages international responsibility and triggers the duty to make reparation. 18 With regard to the form of reparation, in particular, a perusal of the recent practice shows that the Court limits itself to granting satisfaction for the breach of such measures through a finding in its reasoning and one operative paragraph. In other words, the Court states in its judgment on the merits that the concerned State has breached the obligation to execute the provisional measures. The Court even refused to burden the wrongfully be- having State with procedural costs under Article 64 of the Statute, with regard to additional costs provoked by the breach of these measures (e.g. additional pleadings for other provisional measures).19Thisis hardly anincentive to hon- our such measures.

The Court should endeavour to give more teeth to its binding measures under Article 41 of the Statute. One option would be to place procedural costs on the party at fault under a new interpretation of Article 64 of the Statute. Another option would be to impose specific duties of restitution or of compen- sation for all the proximate (as opposed to incidental or remote) consequences of the unlawful act. Still anotheroption would be toelaborate a specific set of consequences for that type of unlawful act, e.g. certain procedural disadvan- tages for the State at fault, thus, that State would not receive certain benefits as long as it had not executed the measures. It also stands to reason that these approaches could be combined. For the time being, the Court seems to be re- maining extremely cautious in this regard. It seems to have been impressed about the leap it dared to take in 2001 and therefore desirous of waiting for some time to pass before carrying further ahead on this subjectmatter.

\section{Other International Tribunals}

Although a review of the law and practice of international tribunals with re- gard to provisional measures is clearly beyond the scope of this article, it is

18 See Articles $28 \mathrm{ff}$. of the International Law Commission's Draft Articles on Responsibility of States for Internationally Wrongful Acts, UN Doc. A/56/10, 2001.

19 See,inparticular,CertainActivities CarriedoutbyNicaraguaintheBorderArea(CostaRica v. Nicaragua), Judgment, 15 December 2015, para. 127, and, as to procedural costs, para. 144 . The decision has been rightly criticized by Judges Tomka, Greenwood, Sebutinde and Judge ad hoc Dugard. 
worth briefly discussing the provisions contained in some international legal instruments related to the settlement of international disputes. In some of them, the binding nature of these measures is uncontroversial. This is the case, in particular, of Article 290 of the Law of the Sea Convention of 1982, which provides that "the court or tribunal may prescribe any provisional measures which it considers appropriate under the circumstances to preserve the re- spective rights of the parties to the dispute or to prevent serious harm to the marine environment, pending the final decision".20

In the same vein, Article 33 (1) of the Revised General Act for the Pacific Settlement of International Disputes reads "the International Court of Justice, acting in accordance with Article 41 of its Statute, or the Arbitral Tribunal, shall lay down within the shortest possible time the provisional measures to be ad- opted. The parties to the dispute shall be bound to accept such measures".21

Similarly, Article 63 (2) of the American Convention on Human Rights and Rule 25 of the Rules of Procedure of the Inter-American Court of Human Rights leave no doubt about the binding nature of provisional measures. Article 63 (2) provides that "in cases of extreme gravity and urgency, and when necessary to avoid irreparable damage to persons, the Court shall adopt such provisional measures as it deems pertinent in matters it has under consideration", whereas under Rule 25 the Court "may, at the request of a party or on its own motion, order such provisional measures as it deems pertinent". The Inter-American Court has consistently indicated that compliance with provisional measures is necessary to ensure the effectiveness of its decisions on the merits and has not hesitated to order the concerned State to adopt provisionalmeasures. 22

The binding nature of provisional measures under the European Convention on Human Rights, on the contrary, has been controversial for several years.

20 P.Tomka, G.I. Hernández, "Provisional Measures in the International Tribunal for the Law of the Sea", in H.P. Hestermeyer et al. (eds.), Coexistence, Cooperation and Solidarity. Liber Amicorum R. Wolfrum (2012), Vol. II, 1763. See PCA Case No. 2015-28, The "Erica Lexie" Incident (Italy v.India), Request for the Prescription of Provisional Measures, 29 April 2016, esp. paras. 72, 120 and 132, at https://pcacases.com/web/sendAttach/1707. An identi- cal provision can be found in Article 31.1 of the European Convention for the Peaceful Settlement of Disputes.

21 The authentic French text reads: "la Cour International de Justice, statuant conformé- ment à l'Article 41 de son Statut, ou le Tribunal arbitral, indiquera, dans le plus bref délai possible, quelles mesures provisoires doivent être prises. Les parties en litige seront tenues de s'y conformer".

22 For a recent example, see Order of the Inter-American Court of Human Rights of May 29, 2013. Provisional Measures withregard toElSalvadorMatterofB, available athttp://www .corteidh.or.cr/docs/medidas/B_se_01_ing.pdf. 
Neither the Convention nor its Protocols expressly refer to provisional mea- sures. In 1991, the European Court of Human Rights (ECtHR) held by a ten to nine majority that the (then) European Commission of Human Rights had not been bestowed by the Convention with the power to adopt mandatory provi- sional measures. 23

On 17 June and 8 July 2002, the European Court of Human Rights inserted Rule 39 according to which the Court may, at the request of a party or of any other person concerned, or of its own motion, indicate to the parties any inter- im measure which it considers should be adopted in the interests of the parties or of the proper conduct of the proceedings. Although Rule 39 is not drafted in clear, mandatory terms, in 2003, the European Court of Human Rights followed without hesitation the ICJ decision in LaGrand and held that:

[interim measures] enable the State concerned to discharge its obliga- tion to comply with the final judgment of the Court, which is legally binding by virtue of Article 46 of the Convention. [...] any State Party to the Convention to which interim measures have been indicated in order to avoid irreparable harm being caused to the victim of an alleged violation must comply with those measures and refrain from any act or omission that will undermine the authority and effectiveness of the final judgment. 24

Two years later, the Grand Chamber upheld the finding and definitively settled the question.25 It must nonetheless be noted that three judges dissented and argued that

23 Cruz Varas and Others v.Sweden, No. 15576/89, Judgment, 20 March 1991, paras. 102-

103. Rule 36 of the Rules of the European Commission on Human Rights reads: "The Commission, or when it is not in session, the President may indicate to the parties any interim measure the adoption of which seems desirable in the interest of the parties or the proper conduct of the proceedings before it".

24 Mamatkulov and Abdurasulovic v. Turkey, No. 46827/99 and 46951/99, Judgment, 6 February 2003, paras. 104-110.

25 Mamatkulov and Askarov v. Turkey, No. $46827 / 99$ and 46951/99, Grand Chamber, 4 February 2005. The Court concluded that "[a] failure by a Contracting State to comply with interim measures is to be regarded as preventing the Court from effectively examin- ing the applicant's complaint and as hindering the effective exercise of his or her right and, accordingly, as a violation of Article 34" (para. 128). On these decisions, see C.J. Tams, "Interim Orders by the ECTHR - Comments on Mamatkulov and Abdurasulovic v. Turkey", 63 Zeitschrift für ausländisches öffentliches Recht und Völkerrecht (2003), 681; K. OellersFrahm, "Verbindlichkeit einstweiliger Massnahmen: Der EMGR vollzieht - endlich - die 
neither Article 26 (d) of that Convention, empowering the Court to enact Rules of Procedure, nor Article 34, instituting the right of individual appli- cation, is sufficiently connected to the issue under consideration to fill a 'gap' in the Convention by instituting binding interim measures ex nihilo, thereby imposing on the States Parties to the Convention an obligation without their consent. In other words, there is a big difference between a simple interpretation of a treaty and its amendment, or between the exercise of the judicial role and international legislation. 26

Since then, the ECtHR has systematically reiterated its position on the binding nature of provisionalmeasures. Inarecentcase, forinstance, itstressed

the special importance attached to interim measures in the Convention system. Their purpose is not only to enable an effective examination of the application to be carried out but also to ensure that the protection afforded to the applicant by the Convention is effective; such measures subsequently allow the Committee of Ministers to supervise the execu- tion of the final judgment. Interim measures thus enable the State con- cerned to discharge its obligation to comply with the final judgment of the Court, which is legally binding by virtue of Article 46 of the Convention. 27

Yet, thebindingnature of provisionalmeasureshasnotgoneunchallengedand States haveoccasionally refused tocomply with them.28InAmirovv.Russia, for instance, the respondent government challenged the legally binding force of the provisional measures and argued that the power to issue such measures cannot be drawn from Article 34 of the Convention or from any other source.29 The developments related to the European Convention on Human Rights further confirm the tendency to affirm the binding character of provisional measures under the different schemes of international adjudication that exist. It has been argued that a general principle of international law has emerged

erforderliche Wende in seiner Rechtsprechung", 30 Europäische Grundrechte Zeitschrift (2003), 689; G. Cohen-Jonathan, "Sur la force obligatoire des mesures provisoires. L'arrêt de la Grande Chambre européenne du 4 février 2005”, 109 Revue Générale de Droit International Public (2005), 421.

26 Mamatkulov and Askarov v. Turkey, supra note 25, Joint Partly Dissenting Opinion of Judges Caflisch, Türmen and Kovler, para. 11.

27 Amirov v.Russia, No.51857/13, Judgment, 27 November 2014, para. 66.

28 See, in particular, W.A. Schabas, The European Convention on Human Rights (2015), 750-751.

29 Amirov v. Russia, supra note 27, para. 62. 
and that any standing international jurisdiction should be presumed to have the power to issue binding provisional measures when they are entitled to "in- dicate", "order", "prescribe" or "adopt" such measures.30 It is against this back- ground that the ICSID jurisprudence has tobe appreciated.

\section{Decisions by ICSID Tribunals}

The adoption of provisional measures by ICSID tribunals is governed by Article 47 of the ICSID Convention and further defined in Rule 39 of the Arbitration Rules.31 In accordance with Article 47 of the ICSID Convention, a tribunal "may, if it considers the circumstances so require, recommend any provisional measures which should be taken to preserve the respective interests of either party" (emphasis added). In the other two authentic languages, namely French and Spanish, Article 47 reads respectively: "le Tribunal peut, s'il estime que les circonstances l'exigent, recommander toutes mesures conservatoires propres à sauvegarder les droits des parties" (emphasis added); and "el Tribunal, si con- sidera que las circunstancias así lo requieren, podrá recomendar la adopción de aquellas medidas provisionales que considere necesarias para salvaguardar los respectivos derechos de las partes".

Under Rule 39 of the Arbitral Rules, in turn,

a party may request that provisional measures for the preservation of its rights be recommended by the Tribunal. The request shall specify the rights to be preserved, the measures the recommendation of which is requested, and the circumstances that require such measures (emphasis added).

30 A. Tzanakopoulos, "Provisional Measures Indicated by International Courts: Emergence of a General Principle of International Law", 57 Revue Hellenique de droit international (2004), 53.

31 In the literature, see, in particular, Z. Mavrogordato, G. Sidere, "The Nature and Enforceability of ICSID Provisional Measures”, 75 Arbitration (2009), 38; G. KaufmannKohler, A. Antonietti, "Interim Relief in International Investment Agreements", in K. Yannaca-Small (ed.), Arbitration under International Investment Agreements: An Analysis of the Key Procedural, Jurisdictional and Substantive Issues (2010), 530; D. Sarooshi, "Provisional Measures and Investment Treaty Arbitration", 29 Arbitration International (2013), 361; S. Luttrell, "ICSID Provisional Measures 'In the Round”, 31 Arbitration International (2015), 393; B. Stern, "Interim/Provisional Measures, Occidental v. Ecuador, ICSID ARB/06/11", in M. Kinnear et al. (eds.), Building International Investment Law. The First 50 Years of ICSID (2016), 627. 
While the French version perfectly coincides with the English one,32 the Spanish version contains a significant difference as it reads

cualquiera de las partes [...] puede solicitar que el Tribunal recomiende la adopción de medidas provisionales para la salvaguardia de sus derechos. La solicitud deberá especificar los derechos que se salvaguardarán, las medidas cuya recomendación se pide, y las circunstancias que hacen necesaria la dictación de tales medidas (emphasis added).

Article 47 of the ICSID Convention and Rule 39 of the Arbitration Rules stand in sharp contrast with Article 26 (1) of the UNCITRAL Arbitration Rules under which arbitral tribunals may, at the request of a party, grant interim measures. With one exception, all tribunals that have dealt with this issue have held that, under Article

47 of the ICSID Convention and Rule 39 of the Arbitration Rules, they have been conferred the power not only to recommend but also to bind the parties with regard to provisional measures.33 In Maffezini v. Spain,

32 The French text reads: "une partie peut [...] requérir que des mesures provisoires pour la conservation de ses droits soient recommandées par le Tribunal. La requête spécifie les droits devantêtre préservés, les mesures dont la recommandation est sollicitée et les circonstances qui rendentcesmesures nécessaires"(emphasis added).

33 Amongst the many decisions in this sense, see Maffezini v. Spain, ICSID Case No. ARB/97/7, Procedural Order No. 2, 28 October 1999, para. 9; Pey Casado and President Allende Foundation v. Chile, ICSID Case No. ARB/98/2, Provisional Measures, 25 September 2001, paras. 19-20; Tokios Tokeles v. Ukraine, ICSID Case No. ARB/02/18, Procedural Order No. 1, 1 July 2003, para. 4; Azurix v. Argentina, ICSID Case No. ARB/01/12, Provisional Measures, 6 August 2003, paras. 30-31; Occidental v. Ecuador, ICSID Case No. ARB/06/11, Provisional Measures, 17 August 2007, para. 58; City Oriente Ltd v. Ecuador and Empresa Estatal de Petróleos del Ecuador, ICSID Case No. ARB/06/21, Provisional Measures, 19 November 2007, para. 52; Perenco Ecuador Limited v. Ecuador, ICSID Case No. ARB/08/6, Provisional Measures, 8 May 2009, para. 43; Burlington Resources Inc. v. Ecuador, ICSID Case No. ARB/08/5, Provisional Measures, 29 June 2009, paras. 62 ff.; Quiborax S.A. and Non-Metallic Minerals S.A. v. Bolivia, ICSID Case No. ARB/06/2, Provisional Measures, 26 February 2010, para. 108, and Award, 15 September 2015, paras. 578-579; Spyridon Roussalis v. Romania, ICSID Case No. ARB/06/1, Award, 7 December 2011, paras. 24 and 29 (Decision on provi- sional measures (not public)); Tethyan v. Pakistan, ICSID Case No. ARB/12/1, Provisional Measures, 13 December 2012, para. 120; RSM Production Corporation v. Saint Lucia, ICSID Case No. ARB/12/10, Request for Security for Costs, 13 August 2014, para. 48; PNGSustainable Development Program Ltd. v. Papua New Guinea, ICSID Case No. ARB/13/33, Provisional Measures, 15 January 2015, para. 102; Transglobal Green Energy, LLC and Transglobal Green Energy de Panama, S.A. v. Panama, ICSID Case No. ARB/13/28, Provisional Measures, 21 January 2016, para. 25; Valle Verde Sociedad Financiera S.L. v. Venezuela, ICSID Case No. 
the tribunal for the first time addressed the question of the hortatory or man- datory character of provisional measures. It took into account only the English and Spanish versions and focused on Rule 39. It held that

[w] hile there is a semantic difference between the word 'recommend' as used in Rule 39 and the word 'order' as used elsewhere in the Rules to describe the Tribunal's ability to require a party to take a certain action, the difference is more apparent than real. It should be noted that the Spanish text of that Rule uses also the word 'dictación'. The Tribunal does not believe that the parties to the Convention meant to create a substan- tial difference in the effect of these two words. The Tribunal's authority to rule on provisional measures is no less binding than that of a final award. Accordingly, for the purposes of this Order, the Tribunal deems the word 'recommend' to be of equivalent value as the word 'order'.34

After the decision in LaGrand was delivered, several ICSID tribunals shared the teleological argument developed by the ICJ with regard to Article 41 of the ICJ Statute. In Pey Casado v. Chile, in particular, the tribunal opined that Article 47 of the ICSID Convention was modelled ("directement inspiré") on Article 41 of the ICJ Statute.35 It borrowed the teleological argument developed by the ICJ in LaGrand to uphold the mandatory character of provisional measures on the need to preserve the (possible) execution of the pending decision on the mer- its and to prevent that a party's acts or omissions could undermine the rights of the other party.36 In Perenco v. Ecuador, the tribunal also included in the equation the term "request", which appears in ICSID Arbitration Rule 39, and concluded that "[t]he parallels between 'recommend' in the ICSID Convention

ARB/12/18, Provisional Measures, 25 January 2016, para. 75; United Utilities (Tallinn) B.V. and Aktsiaselts Tallinna Vesi v.Estonia, ICSID Case No. ARB/14/24, Provisional Measures, 12 May 2016, para. 109.

34 Maffezini v. Spain, supra note 33, para. 9. Other tribunals emphasised the importance of the verb 'dictar' used in the Spanish text, see, for instance, Transglobal v. Panama, supra note 33, para. 25.

35 Pey Casado v. Chile, supra note 33, para. 2, quoted with approval by other tribunals, i.e. CEMEX Caracas Investments B.V. and CEMEX Caracas II Investments B.V. v. Bolivia, ICSID Case No. ARB/08/15, Provisional Measures, 10 March 2010, para. 39. In City Oriente Ltd

v. Ecuador, supra note 33, para. 53, the tribunal held that "[i]n any event, whatever the meaning ascribed to such words, a failure to comply with orders given to Respondents by the Tribunal in accordance with Article 47 of the Convention will entail a violation of Article 26 thereof, and engage Respondents' liability".

Pey Casado v. Chile, supra note 33, paras. 19-20. 
and 'indicate' in the ICJ Statute are quite clear, suggesting that one cannot rightly assume that a 'request' is comparatively weaker than a 'recommenda- tion', or that neither is binding". 37

The argument was fortified by a reference to the principle that the parties to a pending dispute should not take steps that might aggravate it or prejudice the execution of the award.38 In Perencov.Ecuador, the tribunalheld that

[i] rrespective of the precise terminology used, the Tribunal's efforts to effectuate its mandate under a treaty by prevailing on the parties to maintain the status quo in the case before it are binding on the par- ties pursuant to their obligations under said treaty. [...]. In becoming a Party to a treaty such as the ICSID Convention [...], a State confers upon an arbitral tribunal jurisdiction over certain claims and assumes an obli- gation to take whatever steps might be necessary to comply with deci- sions rendered by the tribunal pursuant to the treaty. So long as and to the extent that the arbitration is in progress, both parties are under an international obligation to comply with whatever the tribunal issues as provisional measures for the purpose of protecting its jurisdiction and its ability, should it so decide, to grant the relief requested. State Parties to the ICSID Convention thus inherently are under an international obliga- tion to comply with provisional measures issued by an ICSID tribunal.39

A stream of decisions confirming the mandatory character of provisional mea- sures has followed this line of reasoning.40 Tribunals refrained from under-

37 Perenco Ecuador Ltd. v. Ecuador, note 33, para. 69 in fine. In the same vein, see also City Oriente Limited v. Ecuador, supra note 33, para. 393; Quiborax v. Bolivia, supra note 33, Provisional Measures, para. 108.

38 Para. 24.

39 Perenco v. Ecuador, supra note 33, paras. 66 and 67. In the same vein, in Burlington v. Ecuador, supra note 33, para. 66, the tribunal held that "by ratifying the ICSID Convention, Ecuador has accepted that an ICSID tribunal may order measures on a provisional basis, even in a situation which may entail some interference with sovereign powers and enforcement duties".

40 See the decision referred to in note 33. It must nonetheless be noted that some tribunals have referred only to their authority to recommend provisional measures under Article 47, ICSID Convention; see, for instance, Phoenix Action, Ltd. v. Czech Republic, ICSID Case No. ARB/06/5, Provisional Measures, 6 April 2007, paras. 29-30; Railroad Development Corporation v. Guatemala, ICSID Case No. ARB/07/23, Provisional Measures, 15 October 2008, para. 31; Hydro S.r.l. and others v. Albania, ICSID Case No. ARB/15/28, Provisional Measures, 3 March 2016, paras. 3.7,3.12,3.41 and 5.1. 
taking any detailed analysis of the relevant provisions and simply conformed themselves to what they considered as the consolidated jurisprudence on this point, normally accompanied with reference to acouple of priordecisions.

The following sequence of decisions clearly illustrates how tribunals have built up the jurisprudence on this point. In Tokios Tokelès v. Ukraine, the tribu- nal confined itself to point out that "according to a well-established principle laid down by the jurisprudence of the ICSID tribunals, provisional measures 'recommended' by an ICSID tribunal are legally compulsory; they are in effect 'ordered' by the tribunal, and the parties are under a legal obligation to comply with them".41

Four years later, another tribunal held that "although Article 47 of the ICSID Convention uses the word 'recommend', the Tribunal is, in fact, empowered to order provisional measures. This has been recognized by numerous interna- tional tribunals, among them the ICSID tribunal in the Tokios Tokelés case".42 Another eight years passed and in $P N G$ v. Papua New Guinea the tribunal reiterated the power of ICSID tribunals to order - instead of recommend - provisional measures.43 It refrained from elaborating any legal argument to support this conclusion and laconically relied on a single decision, Occidental

v.Ecuador, which inturn made areference to "numerousinternational tribu- nals", but expressly indicates only the tribunal appointed in Tokios Tokelés v. Ukraine.44

The view that ICSID tribunals may order provisional measures under Article 47 has found limited opposition. In Caratube v. Kazakhstan, the tribunal held, without any explanation, that "according to Rule 39, the Tribunal cannot order, but can only recommend provisional measures in ICSID proceedings". 45 In a more recent case, a dissenting arbitrator argued that the text of Article 47 of the ICSID Convention and Rule 39 of the Arbitration Rules is unequivocal

41 Tokios Tokelés v. Ukraine, supra note 33, para. 4.

42 Occidental v. Ecuador, supra note 33, para. 58.

$43 P N G$ v. Papua New Guinea, ICSID Case No. ARB/13/33, supra note 33, para. 102. In RSM v. Saint Lucia, supra note 33, para. 48, the tribunal held that "[t]here is no question, in general, that the Tribunal has the authority to order provisional measures to preserve a Party's right". Regrettably, it failed to indicate any legal argument - either directly or through prior decisions - to support the finding.

44 Similarly, in United Utilities v. Estonia, supra note 33, para. 109, the tribunal considered that "it has the authority to order, not merely to 'recommend', provisional measures. This has been recognised by many ICSID tribunals, as stated in Tokios Tokelés v. Ukraine" (emphasis added).

45 Caratube International Oil Company LLP v. Kazakhstan, ICSID Case No. ARB/08/12, Provisional Measures, 31 July 2009, para. 67. 
in providing that an ICSID tribunal may recommend - as opposed to order provisional measures. In his words, "no matter how many times it is repeated, an order is not a recommendation. Only in the jurisprudence of an imaginary Wonderland would this make sense". $46 \mathrm{He}$ further fortified the literal interpre- tation with a double acontrario argument. On the one hand, he argued that had the contracting parties to the ICSID Convention intended to confer on ICSID tribunals the power to order provisional measures they would have drafted Article 47 differently and articulated some standards or guidance for grant- ing these measures. On the other hand, he emphasised that, unlike Article 47 of the ICSID Convention, the corresponding article in the Additional Facility Rules - Article 46contains a reference to the provisional measures "ordered" by the tribunal.47 Additionally, the legally binding nature of provisional mea- sures has been occasionallychallenged-withoutsuccess-byStates. 48

Apart from this rather isolated criticism, ICSID tribunals' decisions on provisional measures resemble a litany combining, on the one hand, the admis- sion that the ordinary meaning, the context and the travaux préparatoires of Article 47 of the ICSID Convention militate against the power to order such measures, and, on the other hand, the decisive findings based on the Spanish text of Rule 39 of the Arbitration Rules as well as on the ICJ jurisprudence that provisional measures need to be mandatory in order to fulfil their function, namely to preserve effectively the rights of the parties. The award in Quiborax

v. Bolivia, dealing, inter alia, with the order issued by the tribunal to the respondent to take as a matter of provisional measures all appropriate measures to suspend certain criminal proceedings directly related to the arbitration,49 conveniently states the point. In the tribunal's words,

[i]t is true that the ordinary meaning of this provision, especially the terms 'recommend' and 'should be taken' do not convey the notion of a binding order. The same can be said for the context; other provisions of the ICSID Convention use different language when referring to binding

46 E. Nottingham, dissenting opinion in RSM Production v. Saint Lucia, supra note 33, para. 16.

47 Ibid., para. 4.

48 See, for instance, the position of the respondent in Quiborax v. Bolivia, supra note 33, Award, para. 574 (a).

49 On decisions by investment tribunals related to the continuation of domestic proceed- ings and the related level of deference, see D. Kalderimis, "The Authority of Investment Treaty Tribunals to Issue Orders Restraining Domestic Court Proceedings", 31 ICSID Review (2016), 549, esp. 562-563. 
obligations. Similarly, the travaux préparatoires of the ICSID Convention, to the extent relevant as supplementary means of interpretation, show that an earlier draft using the word 'prescribe' was then changed to 'rec- ommend'. Despite this, ICSID tribunals have consistently found that they have the power to make binding orders for provisional measures. The rationale is that these decisions derive their mandatory force from the function of provisional remedies, which is to secure the applicant's rights while the proceedings are pending. To use the words of the ICJ in LaGrand, 'the power in question is based on the necessity, when the cir- cumstances call for it, to safeguard, and to avoid prejudice to, the rights of the parties as determined by the final judgment of the Court'. While the wording and the context of Article 41 of the ICJ Statute are not strictly identical to those of the ICSID Convention ('indicate' instead of 'recom- mend'), the function of the measures is the same.50

The tribunal also held that failure to adopt the provisional measures ordered under Article 47 amounts to a breach of such provision, but does not neces- sarily entail a violation of the duty to arbitrate in good faith.51 It did not attach any specific consequences to non-compliance with provisional measures. It is generally accepted that ICSID tribunals may take the attitude of the parties regarding provisional measures into account when dealing with the merits of the dispute.

\section{Analysis of Legal Argument in Favour of the Mandatory Character of Provisional Measures according to the Applicable Legal Provisions}

It is submitted that the finding that ICSID tribunals have the power not only to recommend but also to impose provisional measures is not persuasive as a matter of treaty interpretation. In the first place, the focus and insistence

\section{Quiborax v. Bolivia, supra note 33, Award, paras. 578-579. On preparatory work, see infra text note 57 .}

51 The tribunal felt the need to clarify in footnote 743 that "provisional measures issued under Article 47 are binding perse, afailure tocomply with them will automatically entail abreach of Article 47. This does not necessarily give rise to a breach of the underlying right that the measures seek to preserve; whether those rights are harmed will depend on the facts of the case". The tribunal eventually found no breaches of the duty of good faith regarding the procedural conduct in the arbitration, paras. 594-596. 
on Rule 39 of the Arbitration Rules rather than on Article 47 of the ICSID Convention is unfortunate as the former are meant to implement the latter and be "subject to the Convention". 52 As a result, the interpreter must consider first and foremost Article 47 of the ICSID Convention. The Arbitration Rules could be used, when appropriate, to confirm, clarify or determine the meaning attached to Article 47 of the ICSID Convention.

It follows that tribunals are expected to concentrate on Article 47 of the ICSID Convention and to meticulously interpret it in accordance with Articles 31 to 33 of the Vienna Convention on the Law of Treaties (VCLT), keeping in mind that "the text of the treaty is deemed to be the authentic expression of the intentions of the parties; and its elucidation, rather than wide-ranging searches for the supposed intentions of the parties, is the proper object of interpretation." 53

The ordinary meaning of Article 47 of the ICSID Convention is straightforward. All three of the authentic versions of the treaty refer to the power of ICSID tribunals to recommend provisional measures. The verb "to recom- mend" has an unambiguous meaning, which is definitely distinct from that of the verb "to order". In using it in Article 47, the contracting parties to a treaty made a deliberate choice for the purpose of defining the powers of the tribu- nals and the related obligations of the parties to the dispute.

That ICSID tribunals have received the power to recommend, but not to order, provisional measures is fully consistent with the object and purpose of both the treaty as a whole and Article 47 of the ICSID Convention. It cannot be postulated that these objects and purposes, namely ensuring a stable legal framework and an adequate protection of foreign investment, imperatively demand that ICSID tribunals have the competence to order the adoption of provisional measures.

Arbitration Rule 39 can certainly be taken into account as context for the purpose of interpreting Article 47 of the ICSID Convention in accordance with Article 31 (2) of the VCLT. Being meant to implement Article 47, however, Rule 39 cannot dislodge its clear literal meaning. Even assuming, for the sake of ar- gument, that the meaning of Article 47 is not entirely clear, it must be empha- sized that Rule 39 does not point unambiguously to the mandatory character of provisional measures. In all three authentic texts, Rule 39 allows the parties

52 C. Schreuer with L. Malintoppi, A. Reinisch, A. Sinclair, supra note 3, 683.

53 Methanex Corp.v.United States,UNCITRAL(NAFTA), Final Award,3 August2005, PartII, Chapter B, para. 22. Accordingly, as pointed out in Sociedad General de Aguas de Barcelona S.A. v.Argentina, ICSID Case No. ARB/03/17, Jurisdiction, 16 May 2006, para. 54, "[t]he starting place for any exercise in interpretation is therefore the treaty text itself". 
to the dispute to request a Tribunal to recommend the adoption of provisional measures to preserve their rights. And only the Spanish text makes a reference to "la dictación" of provisional measures, which alludes to their mandatory character.54 The use of the term dictación in the Spanish version is the only ele- ment in Rule 39 militating in favour of the mandatory character of provisional measures. However, such an element almost pales in significance compared with the clear and coherent use of the verb "to recommend" in all authentic versions of Article 47 of the ICSID Convention as well as Arbitration Rule 39.

From the standpoint of Article 33 of the VCLT, furthermore, it must be pointed out that the interpreter is not supposed to selectone or several lan- guages, but rather to extract from the treaty "the best reconciliation of the differences".55 Elevating the term dictación used in just one version of Rule 39 to the crucial element for the interpretation of Rule 39 is questionable, espe- cially when considering the rest of the Spanish version as well as the English and French versions, which unmistakably reveal the recommendatory nature of provisional measures. This conclusion is further strengthened by the clear indication contained in the Spanish version of note B to Arbitration Rule 39, published by ICSID in 1968, that "a menos que las partes convengan lo con- trario, el Tribunal sólo tiene la facultadde "hacerrecomendaciones"'.56

Should any doubts remain, they should be dissipated by the travaux préparatoires. The question of the nature of provisional measures was raised during the negotiations and the proposal to confer on tribunals to order their adop- tion was defeated. The verb "to prescribe" that appeared in a previous draft of what would become Article 47 of the ICSID Convention was eventually sup- planted by the verb "to recommend", thus demonstrating the reluctance of the contracting parties to confer on ICSID tribunals the power to order provisional measures.57

54 In City Oriente Ltd v. Ecuador, supra note 33, para. 52, for instance, the tribunal found that the distinction between recommending and ordering "is more apparent than it is real, since Rule 39 (1) itself does, in its Spanish version, mention the 'dictación' [ordering] of the provisional measures, which demonstrates that, as far as the Rules are concerned, such words are used interchangeably".

55 R. Gardiner, Treaty Interpretation (2nd ed., 2015), 380.

56 Reglas procesuales aplicables a los procedimientos de arbitraje, Regla 39, Notas B, p. 105, https://icsid.worldbank.org/apps/ICSIDWEB/resources/Documents/ICSID\%20 Regulations\%20and\%20Rules\%201968\%20-\%20ENG.pdf.

57 See, in particular, Summary Proceedings of the Legal Committee Meeting, 8 December 1964, in A. Broches, History of the ICSID Convention, Vol. II, 812-815. See also Quiborax v.Bolivia, supra note 33, Award, para. 578. On the legislative history of Article 47, see C.N. Brower, R.E.M. Goodman, "Provisional Measures and the Protection of ICSID 
With regard to the LaGrand decision, there is no doubt that ICSID tribunals are allowed - and indeed must be encouraged58 - to look at the legal argu- ments developed by the ICJ as a source of inspiration to interpret investment- related

treaties and to settle investment disputes. Yet, they must make sure thatsuch argumentsaresusceptible tobeing extendedtoinvestmentdisputes, a question that largely depends on the text and content of the relevant legal in- struments, which in the case underdiscussion are Article 41 of the ICJ Statute, Article 47 of the ICSID Convention and Rule 39 of the ICSID Arbitration Rules. In the decisions sketched out above, ICSID tribunals conceded the sig- nificant textual differences between

Article 47 of the ICSID Convention and Article 41 of the ICJ Statute. They nonetheless largely overlooked them and did not see any obstacle to transposing in an almost mechanical fashion to the former the interpretation of the latter adopted

by the ICJ. They passively borrowed the legal argumentelaborated in LaGrand

without inquiring as to the difference between Article 41 of the ICJ Statute and

Article 47 of the ICSID Convention. The former consistently and in all authentic languages uses the verb "to recommend", whereas the latter employs, in the English,

Spanish and French texts, the verb "to indicate". The importance of the difference must not be underestimated since the use of "to recommend" in Article 47 of the ICSID Convention results from a deliberate choice made by the contracting parties, which were well aware of the text of Article 41 of the ICJ Statute. Leaving aside its persuasiveness,59 the legal argument underpinning the LaGrand decision can find

limited application in relation to Article 47 of the ICSID Convention. Two final related considerations - both having a distinct teleological flavour-deserve to be mentioned. The first concerns the well-established principle that the parties to a dispute must refrain from taking measures sus- ceptible to aggravate the dispute or hamperthe execution of the award.60The principle alone does not postulate the power of an arbitral tribunal to order mandatory provisional measures. Otherwise, the entire debate on the horta- tory or mandatory character of provisional measures that opposed leading

Jurisdictional Exclusivity against Municipal Proceedings", 6 ICSID Review (1991), 431, esp. 440 ff.; A.R. Parra, The History of ICSID (2012), esp. $173 \mathrm{ff}$.

58 A.Pellet, “TheCase Law of the ICJ in Investment Arbitration", 28ICSID Review (2013), 223.

59 See Section III.

60 See, for instance, Amco Asia Corporation and others v. Indonesia, ICSID Case No. ARB/81/1, Provisional Measures, 9 December 1983, 1 ICSID Reports (1993), 401, 411. In Caratube v. Kazakhstan, supra note 45, para. 67, the tribunal held that "the Parties have an obligation to conduct the procedure in good faith and that this obligation includes a duty to avoid any unnecessary aggravation of the dispute and harassment of the other party". 
scholars for decades would not have made any sense. The existence of such an obligation and the legal nature of a decision by a tribunal on provisional measures are two different questions. The parties to a dispute must comply with the obligations stemming from the principle independently from the powers conferred on the tribunal or their exercise. 61

The second consideration relates to the consequences of disregarding a tri- bunal's recommendation on provisional measures. During the negotiation of the ICSID Convention, a proposal that intended to introduce a sanction for non-compliance with these measures was rejected.62 Instead, it was agreed that ICSID tribunals would "take into account" such conduct.63 Some authors have associated the fact that tribunals could take into account the reluctance of any party to adopt the recommended measures with a "moral obligation" to do so.64 Be that as it may, the very fact that no sanction was attached to non- compliance seems to confirm - or at least to be compatible with - the horta- tory nature of such provisional measures.

\section{Relevance of the Attitude of ICSID Members}

If it is accepted that the interpretation upheld in the decisions sketched out above is not persuasive, it is appropriate to inquire with regard to what the consequences and implications may be.65 From this perspective, it must be kept in mind that the parties to a treaty remain "the transaction's exclusive and absolute domini" 66 and that international rules - including those contained in

61 In Churchill Mining Plc and Planet Mining Pty Ltd v. Indonesia, ICSID Case No. ARB/12/14 and 12/40, Provisional Measures, 4 March 2013, para. 57, the tribunal held that "[w]hile the request for provisional measures must be denied, the Tribunal reminds the Parties of their general duty, which arises from the principle of good faith, not to take any action that may aggravate the dispute or affect the integrity of the arbitration". See also text and note 51.

62 See A.R. Parra, supra note 57, 86.

63 A. Broches, supra note 57, p. 815; A.R. Parra, supra note 57, 178.

64 G. Kaufmann-Kohler, A. Antonietti, supra note 31, 546.

65 Significantly, in Quiborax v. Bolivia, Award, supra note 33, paras. 582 and 583, the tribunal conceded that the attribution of mandatory character to provisional measures can be seen as an "evolution of international law" with regard not only to investment arbitration, but also to the jurisprudence of the ICJ and the ECtHR. It even prospected the possibility that the respondent "may not have been aware of the binding nature of these provisional measures when it failed to comply with them".

66 Expression borrowed from G. Arangio-Ruiz, The UN Declaration on Friendly Relations and the System of the Sources of International Law (1979), 284-285, esp. note 183. In Canadian 
international agreements - are created, modified and discarded through claims, counterclaims, actions and reactions by the subjects of international law.67

Given the significant number of coherent decisions upholding the manda- tory character of provisional measures, it is not surprising that ICSID tribu- nals have recently limited themselves to referring to these decisions and have been reluctant to engage in a full discussion on the matter. Such an attitude is likely to be consolidated in future decisions. True, each tribunal is not legally bound by previous decisions.68 But it is also expected to consider and follow established case law to the fullest possible extent, with a view to enhancing the coherence and predictability of the whole system.69 As pointed out by an ICSID tribunal,

unless there are compelling reasons to the contrary, it ought to follow solutions established in a series of consistent cases, comparable to the case at hand, but subject of course to the specifics of a given treaty and of the circumstances of the actual case. By doing so, it will meet its duty to seek to contribute to the harmonious development of investment law and thereby to meet the legitimate expectations of the community of States and investors towards certainty of the rule of law.70

Yet, the crux of the matter remains the subsequent practice of the parties to the ICSID Convention with a view to establishing the possible informal modifica- tion of Article 47 in the sense of allowing ICSID tribunals to order provisional

Cattleman for Fair Trade v. United States (UNCITRAL) NAFTA, the respondent clearly pointed out that "a treaty remains the exclusive province of the States parties themselves that may construct the treaty either expressly or tacitly through subsequent conduct", Reply by the United States, 1 May 2007, p. 11 (emphases added, footnotes omitted), http:// www.state.gov/documents/organization/84471.pdf.

67 See M.S. McDougal, "The Hydrogen Bomb Tests and the International Law of the Sea”, 49 American Journal of International Law (1955), 353.

68 See, among many decisions, AES Corp. v. Argentina, ICSID Case No. ARB/02/17, Jurisdic- tion, 26 April 2005, para. 30.

69 On this point, H. Lauterpacht, The Development of International Law by the International Court (1958), p. 14, has eloquently pointed out that the ICJ "follows its own decisions for the same reasons for which all courts - whether bound by the doctrine of precedent or not-do so, namely, because such decisions are a repository of legal experience to which it is convenient to adhere; because they embody what the Court has considered in the past to be good law; because respect for decisions given in the past makes for certainty and stability, which are the essence of the orderly administration of justice[...]".

70 Bayindir Insaat Turizm Ticaret Ve Sanayi AS v. Pakistan, ICSID Case No. ARB/03/29, Award, 27 August 2009, para. 145. 
measures. Article 31 (3) (b) of the VCLT clearly directs the interpreter to take into account any subsequent practice in the application of the treaty estab- lishing the agreement of the parties regarding its interpretation.71 From this perspective, the WTO Appellate Body has lucidly pointed out that this requires "a "concordant, common and consistent' sequence of acts or pronouncements which is sufficient to establish a discernible pattern implying the agreement of the parties [to a treaty] regarding its interpretation". 72

It therefore becomes crucial to assess the reaction or lack of reaction of the parties to the ICSID Convention. In this regard, it must first be emphasized that arbitral decisions cannot be treated as State practice. 73 They remain the pronouncements of arbitral tribunals that have been mandated by the parties to settle a specific dispute between them. Strictly speaking, the effects of their decisions are confined to the parties to the dispute. They may, nonetheless, in- fluence State practice and trigger States' reactions either in support or against the interpretation taken by the tribunal. The lack of reaction to or the acqui- escence in a consistent and significant body of decisions may amount to State practice and demonstrate the general acceptance by the parties to the treaty of the interpretation emerging from the arbitral decisions even to the point of informally modifying the treaty through subsequent practice.74 Acceptance by the disputing investor, on the contrary, is immaterial for the purpose of State practice, as only the States parties are the masters of the treaty. What is decisive is to establish whether State practice - rather than arbitral decisions - is sufficiently concordant, common and consistent.75

With regard to the mandatory character of provisional measures, it is consequently the general acceptance of or acquiescence in arbitral tribunals' de- cisions by the parties to the ICSID Convention that may lead-or may have

71 See, for instance, Kasikili/Sedudu Island (Botswana/Namibia), Judgment, I.C.J. Reports 1999 (II), p. 1045, esp. paras. 49-50.

72 Japan-MeasuresAlcoholic Beverages, WT/DS8/AB/R,4October 1996, para. 106. See also Canadian Cattlemen v. United States, supra note 66, para. 189.

73 In Romak S.A. v. Uzbekistan, UNCITRAL AA280, Award, 26 November 2009, para. 170, the tribunal held that arbitral awards "cannot be deemed to constitute the expression of a general consensus of the international community, and much less a formal source of international law. Arbitral awards remain mere sources of inspiration, comfort or refer- ence to arbitrators".

74 See R. Kolb, Bonne foi, supra note 7, 297 ff. See also W. Karl, Vertrag und spätere Praxis im Völkerrecht (1983).

75 See, with regard to the so-called 18-month requirement contained in some BITs con- cluded by Argentina, Daimler Financial Services AG v. Argentina, ICSID Case No. ARB/05/1, Award, 15 August 2012, para. 268. 
already led - to an informal modification of Article 47 of the ICSID Convention. From this perspective, the presence of two elements must be shown. On the one hand, a significant number of arbitral tribunals must have shared the inter- pretation outlined above. On the other hand, the great majority of the parties to the treaty, having had ample opportunity to react to the interpretation, must have endorsed the new reading of the relevant provision or have refrained from contesting its inaccuracy.

In the case of Article 47 of the ICSID Convention and Rule 39 of the ICSID Arbitration Rules, both elements seem to be satisfied. The decisions adopted by the various arbitral tribunals can be considered as having been sufficiently coherent and as having reached the critical mass. They were rendered during a time-span of about 16 years and there is little record of any negative reac- tion by States, either of those appearing as respondents in proceedings or by other States. Although the fact that not all investment awards are available to the public calls for prudence, it may be concluded that a uniform and gener- ally accepted practice has emerged allowing ICSID tribunals to order binding provisional measures. Indeed, had the parties to the Convention perceived the decisions described above as an impairment of their rights or an alteration of their obligations, they would have had a bona fide duty to oppose them.

\section{Conclusions}

A string of decisions rendered by ICSID tribunals since 1999 have upheld virtually without opposition during the proceedings and amongst the parties to the ICSID Convention - the mandatory character of provisional measures under Article 47 of the ICSID Convention and Rule 39 of the ICSID Arbitration Rules. The legal arguments underpinning these decisions and principally the Spanish version of Rule 39 as well as teleological considerations developed along the lines of the ICJ decision in LaGrand are not entirely convincing. Nonetheless, tribunals appear to consider these decisions as "jurisprudence constante" and have confined themselves to refer to them without much elab- oration and with an almost religious deference.

However, it is argued that these decisions imply a significant departure from the meaning the contracting parties recorded in the treaty. Such a law- making exercise does not suffice in itself to confer on an ICSID tribunal the competence not only to recommend, but also to order, these measures. If the overwhelming majority of ICSID members endorse, accept or at least acquies- cence in these decisions, however, an informal modification of Article 47 may be brought about. This is arguably what has happened in the last few years 
since these decisions have reached a critical mass and ICSID membership has acquiesced in the power of ICSID tribunals to order provisional measures.

Attributing mandatory force to provisional measures can be deemed a welcome development from the point of view of the efficiency of investment arbitration and compliance with related awards. This is at once a chance and a burden. It will also bring ICSID jurisprudence in line with that of other inter- national tribunals and most prominently the ICJ. It can additionally be seen as another milestone in the rise of provisional measures to the legal Olympus of binding legal acts. Here, as in other treaty matters, the attitude of States parties is the decisive element. By remaining ostensibly silent, States may thus have brought about a significant shift in the legal situation. Indeed, they are the masters of the treaty, even when they remain silent. As Humpty Dumpty reminds us, the real question is "whichistobemaster-that's all."76

76 L. Carroll, Through the Looking Glass (1960), Chapter VI, 186. 